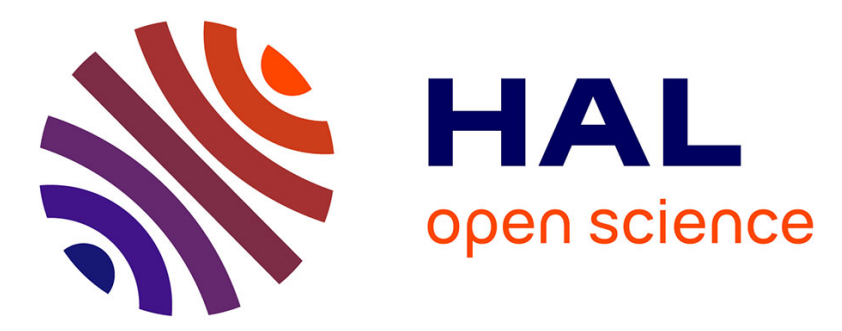

\title{
Towards Sustainable Manufacturing through Collaborative Circular Economy Strategies
}

Leila Saari, Vafa Järnefelt, Katri Valkokari, Jorge Tiago Martins, Federica Acerbi

\section{- To cite this version:}

Leila Saari, Vafa Järnefelt, Katri Valkokari, Jorge Tiago Martins, Federica Acerbi. Towards Sustainable Manufacturing through Collaborative Circular Economy Strategies. 22nd Working Conference on Virtual Enterprises (PRO-VE 2021), Nov 2021, Saint-Etienne, France. pp.362-373, 10.1007/9783-030-85969-5_33. emse-03339428

\section{HAL Id: emse-03339428}

\section{https://hal-emse.ccsd.cnrs.fr/emse-03339428}

Submitted on 24 Nov 2021

HAL is a multi-disciplinary open access archive for the deposit and dissemination of scientific research documents, whether they are published or not. The documents may come from teaching and research institutions in France or abroad, or from public or private research centers.
L'archive ouverte pluridisciplinaire HAL, est destinée au dépôt et à la diffusion de documents scientifiques de niveau recherche, publiés ou non, émanant des établissements d'enseignement et de recherche français ou étrangers, des laboratoires publics ou privés. 
Saari L., Järnefelt V., Valkokari K., Martins J.T., Acerbi F. (2021) Towards Sustainable Manufacturing Through Collaborative Circular Economy Strategies. In: Camarinha-Matos L.M., Boucher X., Afsarmanesh H. (eds) Smart and Sustainable Collaborative Networks 4.0. PRO-VE 2021. IFIP Advances in Information and Communication Technology, vol 629. Springer, Cham. https://doi.org/10.1007/978-3-030-85969-5_33

\title{
Towards Sustainable Manufacturing through Collaborative Circular Economy Strategies
}

\author{
Leila Saari ${ }^{1}$, Vafa Järnefelt ${ }^{2}$, Katri Valkokari ${ }^{3}$, Jorge Tiago Martins ${ }^{2}$ and \\ Federica Acerbi ${ }^{4}$ \\ ${ }^{1}$ VTT Technical Research Centre of Finland Ltd, Kaitoväylä 1, Oulu, Finland \\ ${ }^{2}$ VTT Technical Research Centre of Finland, Tekniikantie 21, 02150 Espoo, Finland \\ ${ }^{3}$ VTT Technical Research Centre of Finland, Visiokatu 4, 33720 Tampere, Finland \\ ${ }^{4}$ Department of Management, Economics and Industrial Engineering, Politecnico di Milano, \\ Piazza Leonardo da Vinci 32, 20133 Milan, Italy \\ \{Vafa.Jarnfelt, Leila.Saari, Katri.Valkokari,Jorge.Martins\}@vtt.fi, \\ Federica.Acerbi@polimi.it
}

\begin{abstract}
The principles of a circular economy (CE) — social, economic and environmental - could enhance the sustainability of the manufacturing sector, but radical transitions and collaboration are required in order to fully engage with this paradigm change. This study is based on the assumption that, through collaborative strategies, a $\mathrm{CE}$ could transform the inefficiencies of linear value chains into novel competitive advantages for manufacturing companies. This conceptual paper presents a framework that integrates the identified inefficiencies of linear manufacturing value chains and an assessment model describing the five maturity levels of CE. At the lowest level-linearity - there is no collaboration; at the next - industrial piloting - experiments are conducted with discrete pilot projects within supply-chain partners. The third level-systemic material management - cannot be achieved without close collaboration and fair data exchange, while the next level-CE thinking — envisages a closed-loop supply chain. The highest level — full circularity — contributes not only to environmental, but also to economic and social sustainability. This paper argues that the identification of novel value circles and the co-creation of value with a variety of partners are crucial aspects for enabling the $\mathrm{CE}$ transition.
\end{abstract}

Keywords: circular economy, connected factories, collaboration, manufacturing companies, digitalisation, supply chain,

\section{Introduction}

The manufacturing industry-as, increasingly, with all industries - is faced with the challenging requirements of a transition to sustainability, which, in the literature, is discussed mainly from an environmental perspective, while the social and economic dimensions are often neglected [1]. Despite the term being widely used, the definition of $\mathrm{CE}$ is rather vague, and most of the literature has focused on one specific region or 
on a specific CE-related application [2]. A broader formulation of consistent CE strategies therefore remains a challenge [1],[3]. In line with the collaborative networks approach, we highlight the system perspectives and use Korhonen et al.'s definition: ' $C E$ is an economy constructed from societal production-consumption systems that maximizes the service produced from the linear nature-society-nature material and energy throughput flow. This is done by using cyclical materials flows, renewable energy sources and cascading type energy flows. Successful CE contributes to all the three dimensions of sustainable development. CE limits the throughput flow to a level that nature tolerates and utilises ecosystem cycles in economic cycles by respecting their natural reproduction rates' [4].

In this paper, we present a $\mathrm{CE}$ matrix for the manufacturing sector, which aims to assist in i) identifying the level of $\mathrm{CE}$ at which a company operates and ii) the needs for improvements and collaboration that would enable the next maturity level of circularity to be achieved. The CE matrix seeks to translate the maturity levels of CE to help in conceptualising the sustainability vision of a company and to provide a conceptual framework for an elaborated roadmap to that vision's realisation.

\section{Relationship with Existing Theories and Research}

The principles characterising $\mathrm{CE}$ are a great driver for sustainable industrial systemsespecially for the manufacturing sector [5], where it is called circular manufacturing [6]. In the context of the manufacturing industry, the regeneration of resources happens through different strategies, which, if adopted concurrently, support the sustainable development of manufacturing firms. Thus, there remains a clear need to identify novel, promising innovations to shift from linear business models to circular ones [7].

There are two main cycles typically identified within CE concepts: biological and technical [8]. In parallel with a sustainable transition, a digital transition disrupts ways of doing business, enabling, by the flow of information, more effective product and material circulation [9],[10]. CE implies not only decreasing one's own environmental footprint within the take-make-dispose model, but also interacting with the supply chain to optimise the entire materials loop. Thus, collaboration is a crucial enabler of sustainability [11] that can be practically implemented using Industry 4.0 technologies [12] and is necessary to enable interaction and fair data exchange between companies [13].

The CE provides opportunities to turn the inefficiencies of linear value chains (unsustainable materials, underutilised capacity, prematurely ended product lives, wasted end-of-life value and unexploited customer engagement [Fig. 1] [14]) into business value. However, due to production and consumption often taking place in different countries, supply chains may need to be reorganised to facilitate reuse and remanufacturing, and product lifetimes can be extended by upgradeability [15]. Collaborative incentives throughout the supply chain are needed for companies to actively consider sustainable materials, durability and reparability. 


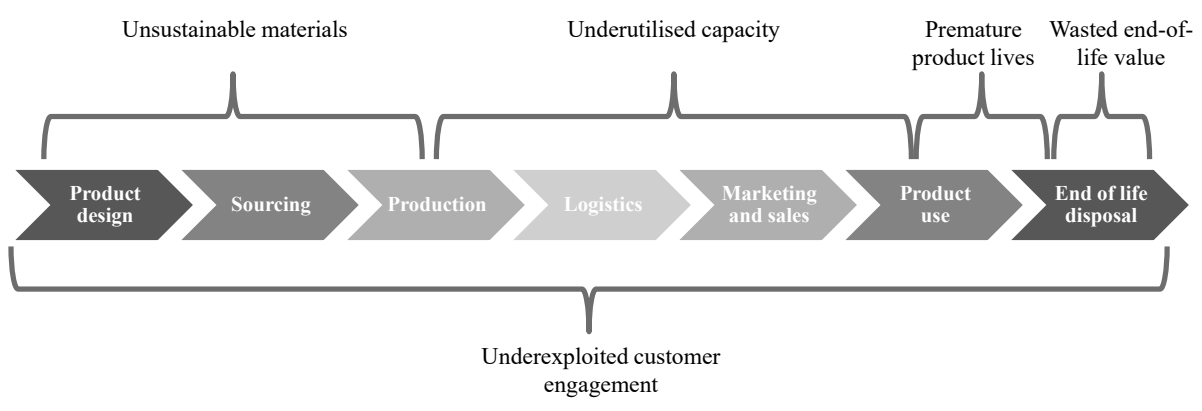

Fig. 1. Substantial inefficiencies may occur in all parts of the manufacturing value chain. Adapted from [14].

To overcome inefficiencies along the manufacturing value chain, deeper investigation is needed of the distinct points at which the different levels of CE strategies can be implemented. Collaborative strategies are needed to enable meta- and macro-level transitions [16] - that is, to broaden the approach from the concept of sustainable islands [17] towards a green transition - and the environmental challenge calls for commitment from and collaboration by companies, industries and authorities [18].

However, companies face difficulties in deciding how to examine and proceed with the sustainability transition [19], and various methods and tools have been developed to guide them in their CE transformation journeys. For example, Blomsma et al. [20] created the Circular Strategies Scanner, a tool to support the visualisation of circularoriented innovation, to make the CE concept more tangible, to map ongoing circular initiatives and to generate new ideas for circularity. Unal and Shao [21] provided a taxonomy of strategies for CE implementation; according to the authors, despite common assumptions, companies cannot make simultaneous improvements to all CE practices simply by emphasising them equally, and need to select a CE collaboration strategy such as trade-off, cumulative model or threshold model.

Organisational sustainability readiness can be assessed with tools that are based on capability maturity models [22],[23],[24], and the ManuMaturity tool has been highlighted as an example of an implemented maturity tool that includes the sustainability dimension [25]. Its sustainability dimension has two questions: "How are resources used?" and "How are environmental impacts considered?" Applicable tools are included in the CE playbook for Finnish SMEs [14], including ecosystem partner identification and technology maturity assessment.

The CE pathway developed in the Connected Factories 2 (CF2) project raises awareness and highlights the importance of the CE paradigm for the sustainability of the manufacturing sector. The CE maturity levels are i) linearity, ii) industrial CE piloting, iii) systemic material management, iv) CE thinking and v) full circularity. Each level is described in more detail in Table 1 [26]. 
Table 1. CE maturity level descriptions.

\begin{tabular}{ll}
\hline Level & Description \\
\hline Full circular- & Company has achieved full circularity of products, processes and operations, \\
ity & which are sustainable on the environmental, social and economic levels. This \\
is accomplished by a broad understanding of value flows (such as synergies \\
among forward and reverse logistics, local value chains and zero-waste man- \\
ufacturing) and the co-creation of new value circles within manufacturing \\
networks (such as flexible remanufacturing networks, upgrading of products \\
and on-demand production) as a key managerial practice.
\end{tabular}

\section{Research Methods}

The aim of this paper is to identify collaborative CE strategies that can boost the transition towards a sustainable manufacturing industry. Through the lens of design science [27], the goal of exploratory researchers is to develop a 'means to an end' - an artefact to solve a practical problem. In our study, the practical managerial challenge and the research question were distilled to 'How can collaborative CE strategies enhance the transition towards sustainable manufacturing industry?' The conceptual framework for sustainable industrial systems was constructed through a literature review that combined the relevant streams of literature: circularity in value chains, collaborative (CE) strategies and CE maturity assessment. Based on this preliminary framework, a matrix combining value chain analyses and $\mathrm{CE}$ maturity assessments was configured.

The framework building and testing was conducted in collaboration with CF2 research practitioners [28]. The preliminary framework was presented and tested in the Pathways to Digitalisation of Manufacturing and Associated Use Cases webinar on Wednesday $24^{\text {th }}$ March 2021, organised by the European Factories of the Future Research Association (EFFRA). Out of 77 people registered, 55 attended the webinar; 
three represented associations or standardisation organisations, seven consultancies, 14 industrial companies and 31 research organisations. Feedback was collected in an interactive session via an online collaborative whiteboard platform, the Miro board. Information on the pilot projects was also gathered during the workshop, particularly case examples of the different development pilots of companies seeking to solve identified value chain inefficiencies at each CE maturity level. The input from workshop- the development pilots illustrating the CE strategies and readiness of companies in the context of the manufacturing industry [22] — was analysed, and the matrix was finalised by the researchers.

Instances of collaboration were identified in the solutions implemented in CF2 projects, see Table 2 .

Table 2. Collaboration in the solutions of CF2 projects.

\begin{tabular}{|c|c|c|}
\hline Level & Instance of collaboration & Projects and solutions \\
\hline Linearity & $\begin{array}{l}\text { No collaboration, preva- } \\
\text { lence of make-take-dispose } \\
\text { paradigm. }\end{array}$ & No instances among CF2 projects. \\
\hline $\begin{array}{l}\text { Industrial } \\
\mathrm{CE} \text { pilot- } \\
\text { ing }\end{array}$ & $\begin{array}{l}\text { Collaboration and experi- } \\
\text { mentation with external in- } \\
\text { dustrial actors, with an em- } \\
\text { phasis on production and lo- } \\
\text { gistics. }\end{array}$ & $\begin{array}{l}\text { QU4LITY: quality pilots on the reduction of un- } \\
\text { necessary scrap material and augmented reality } \\
\text { (AR) demos to support the maintenance. } \\
\text { European Factory Platform: logistics traceabil- } \\
\text { ity via blockchain. }\end{array}$ \\
\hline $\begin{array}{l}\text { Systemic } \\
\text { material } \\
\text { manage- } \\
\text { ment }\end{array}$ & $\begin{array}{l}\text { Integrated concerns with } \\
\text { opportunities to reuse, re- } \\
\text { furbish, recycle and reman- } \\
\text { ufacture materials. }\end{array}$ & $\begin{array}{l}\text { Kyklos: automatic product design for a person- } \\
\text { alised 3D-printed wheelchair with AR manuals. } \\
\text { TRICK: tracing 'from sheep to shop' via block- } \\
\text { chain. } \\
\text { European Factory Platform: digital marketplace } \\
\text { with automated B2B matchmaking and new } \\
\text { market opportunities. } \\
\text { AI.SOV: AI-based solution to forecast and opti- } \\
\text { mise spare parts production. }\end{array}$ \\
\hline $\begin{array}{l}\text { CE } \\
\text { thinking }\end{array}$ & $\begin{array}{l}\text { Commitment to an indus- } \\
\text { trial symbiosis network in } \\
\text { which the ultimate goal is to } \\
\text { leverage a closed-loop sup- } \\
\text { ply chain. }\end{array}$ & $\begin{array}{l}\text { Kyklos: in addition to the web-based configura- } \\
\text { tion tool (a digital twin), the IoT is embedded in } \\
\text { the product, enabling predictive maintenance. } \\
\text { European Factory Platform: smart waste man- } \\
\text { agement with connected factories, real-time } \\
\text { data analytics and blockchain. }\end{array}$ \\
\hline $\begin{array}{l}\text { Full } \\
\text { circularity }\end{array}$ & $\begin{array}{l}\text { Aspirational goals reflect- } \\
\text { ing a broad understanding } \\
\text { of value flows and the co- } \\
\text { creation of new value cir- } \\
\text { cles within manufacturing } \\
\text { networks. }\end{array}$ & None to date. \\
\hline
\end{tabular}

The co-development of the framework to integrate the CE maturity levels and the analysis of the value chain processes together entailed the identification-by the participating companies - of solutions to the challenges encountered at each self-assessed stage 
of maturity and how they intersect with the various stages of the value chain: product design, sourcing, production, logistics, marketing \& sales and product use.

\section{Preliminary Conceptual Framework for a Sustainable and Circular Manufacturing Industry}

Our framework combines the linear value chain [14] and the maturity levels of the CE pathway [26] into a matrix in which the value chain appears as rows and the maturity levels as columns, as shown in Table 3. The illustration of the embodiment and performance of the company in each cell guides both the assessment and identification of further steps in developing sustainable manufacturing.

\section{Conclusions and Future Work}

In this paper, we presented a matrix that combines the $\mathrm{CE}$ maturity levels defined in the CF2 project with the linear value chain. The readiness (or maturity) assessment enables capability-building and a sustainable manufacturing strategy, which is made visible via solutions and development pilots that decrease environmental impact and increase collaboration along the supply chain. The collaboration viewpoint emerges when moving from the linearity level towards full circularity. Collaboration also indicates data exchange along the supply chain, which was a key enabling element in the CE solutions presented in the webinar.

At the linearity level, no collaboration takes place, while industrial piloting indicates some goals, trials and pilots around production and logistics that remain discrete and do not flow through material management processes. Systemic material management invites R-cycles, like the reuse, refurbishment, recycling and remanufacturing of materials. The CE thinking level envisions the closed-loop supply chain, and the highest level-full circularity - contributes not only to environmental, but also to economic and social sustainability, but is not possible without collaboration.

Companies need methods and tools to guide them in their CE transformation strategy and journey. The proposed preliminary framework enables the assessment of CE maturity along the manufacturing value chain and seeks to upgrade that maturity level, contribute to the CE strategy of the company and provide options to proceed with both collaboration and digital solutions that require data exchange.

Critically, the linear model is insufficient to the transition towards a sustainable industry because it neglects the values and interests of other actors in the value chain, and sustainability needs to be approached through collaboration and jointly set goals, steps and practices. Collaboration can leverage the CE by turning the inefficiencies of linear value chains into novel competitive advantages for the manufacturing industry. Potential approaches, such as circular supply chain and product-as-a-service, require strategic collaboration within both business models and solution development.

In the next paper, we will present the results of assessments of company pilots; validation will be done with pilots from the CF2 project. 
Table 3. CE maturity levels mapped with the linear value chain

\begin{tabular}{|c|c|c|c|c|c|}
\hline $\begin{array}{l}\text { Linear } \\
\text { value } \\
\text { chain }\end{array}$ & Linearity & Industrial CE piloting & $\begin{array}{l}\text { Systemic material man- } \\
\text { agement }\end{array}$ & CE thinking & Full circularity \\
\hline $\begin{array}{l}\text { Product } \\
\text { design }\end{array}$ & $\begin{array}{l}\text { Product design does not } \\
\text { consider durability, up- } \\
\text { gradeability, circularity } \\
\text { or sustainability. }\end{array}$ & $\begin{array}{l}\text { Company considers tran- } \\
\text { sition from the use of un- } \\
\text { sustainable and hazardous } \\
\text { substances to sustainable } \\
\text { raw materials. Company } \\
\text { has piloted the repair or } \\
\text { reuse of products. }\end{array}$ & $\begin{array}{l}\text { Durability and upgradea- } \\
\text { bility of products is pro- } \\
\text { moted and applied. Per- } \\
\text { sonalisation of products } \\
\text { is driven by demand and } \\
\text { purpose. }\end{array}$ & $\begin{array}{l}\text { Environmental impact as- } \\
\text { sessment is a driving } \\
\text { force of product develop- } \\
\text { ment (eco design). Prod- } \\
\text { ucts are designed to avoid } \\
\text { loss and premature end- } \\
\text { of-life. }\end{array}$ & $\begin{array}{l}\text { Products are fully circular } \\
\text { by design, enhancing pur- } \\
\text { pose-based durability } \\
\text { during the life-cycle and } \\
\text { enabling multiple reuse, } \\
\text { repair, remanufacturing } \\
\text { and regenerative recy- } \\
\text { cling at end-of-life. }\end{array}$ \\
\hline Sourcing & $\begin{array}{l}\text { No actions to reduce the } \\
\text { consumption of energy } \\
\text { and/or materials are being } \\
\text { implemented. Materials } \\
\text { are sourced based on per- } \\
\text { formance and price. }\end{array}$ & $\begin{array}{l}\text { Company seeks to mini- } \\
\text { mise inputs of energy and } \\
\text { materials. Material sourc- } \\
\text { ing is being shifted from } \\
\text { unsustainable to sustaina- } \\
\text { ble raw materials. }\end{array}$ & $\begin{array}{l}\text { Sourcing is based on code } \\
\text { of conduct guidelines for } \\
\text { circularity and the sus- } \\
\text { tainability of materials. } \\
\text { The amount of waste is } \\
\text { minimised and side } \\
\text { streams are utilised. }\end{array}$ & $\begin{array}{l}\text { Raw materials are } \\
\text { sourced mainly from } \\
\text { known and monitored } \\
\text { secondary markets and } \\
\text { through reverse logistics. } \\
\text { Social impacts are con- } \\
\text { sidered in the sourcing } \\
\text { process. }\end{array}$ & $\begin{array}{l}\text { Full circularity is enabled } \\
\text { by sustainable materials } \\
\text { that have less environ- } \\
\text { mental impact (on biodi- } \\
\text { versity, climate change, } \\
\text { acidification, etc.) than } \\
\text { traditional counterparts. }\end{array}$ \\
\hline
\end{tabular}




\begin{tabular}{|c|c|c|c|c|c|}
\hline $\begin{array}{l}\text { Linear } \\
\text { value } \\
\text { chain }\end{array}$ & Linearity & Industrial CE piloting & $\begin{array}{l}\text { Systemic material man- } \\
\text { agement }\end{array}$ & CE thinking & Full circularity \\
\hline Logistics & $\begin{array}{l}\text { Company has no goal to } \\
\text { optimise logistics. }\end{array}$ & $\begin{array}{l}\text { Logistics optimisation pi- } \\
\text { lots are taking place. }\end{array}$ & $\begin{array}{l}\text { In addition to deliveries, } \\
\text { logistics covers raw mate- } \\
\text { rials and waste. }\end{array}$ & $\begin{array}{l}\text { Linear and reverse logis- } \\
\text { tics are considered with } \\
\text { partners. Traceability of } \\
\text { products is implemented. }\end{array}$ & $\begin{array}{l}\text { Value chains are local- } \\
\text { ised, and closed loops are } \\
\text { implemented. Transpar- } \\
\text { ency of products, produc- } \\
\text { tion and logistics is ena- } \\
\text { bled. }\end{array}$ \\
\hline $\begin{array}{l}\text { Product } \\
\text { use }\end{array}$ & $\begin{array}{l}\text { Products are not reused or } \\
\text { repaired during their life- } \\
\text { cycles. }\end{array}$ & $\begin{array}{l}\text { Pilots are undertaken for } \\
\text { reuse and for the recovery } \\
\text { of materials from used } \\
\text { products. }\end{array}$ & $\begin{array}{l}\text { Production plans are } \\
\text { based on an analysis of } \\
\text { multisource product usage } \\
\text { data. }\end{array}$ & $\begin{array}{l}\text { Understanding customer } \\
\text { behaviour and needs ena- } \\
\text { bles a prolonged life-cy- } \\
\text { cle, upgrades and repairs } \\
\text { to products. }\end{array}$ & $\begin{array}{l}\text { Sharing economy busi- } \\
\text { ness models provide novel } \\
\text { alternatives for product } \\
\text { usage. }\end{array}$ \\
\hline
\end{tabular}


Acknowledgements. This work has been supported by funding from the European Union's Horizon 2020 research and innovation programme under grant agreement 873086 (Connected Factories 2) as part of the Factories of the Future Public-Private Partnership initiative.

\section{References}

[1] M. M. Bjørnbet, C. Skaar, A. M. Fet, and K. Ø. Schulte, 'Circular economy in manufacturing companies: A review of case study literature', J. Clean. Prod., vol. 294, Apr. 2021, Art. no. 126268 .

[2] M. Alnajem, M. M. Mostafa, and A. R. ElMelegy, 'Mapping the first decade of circular economy research: A bibliometric network analysis', J. Ind. Prod. Eng., vol. 38, no. 1, pp. 29-50, Jan. 2021.

[3] J. Kirchherr, D. Reike, and M. Hekkert, 'Conceptualizing the circular economy: An analysis of 114 definitions', Resour. Conserv. Recycl., vol. 127, pp. 221-232, Dec. 2017.

[4] J. Korhonen, A. Honkasalo, and J. Seppälä, 'Circular economy: The concept and its limitations', Ecol. Econ., vol. 143, pp. 37-46, Jan. 2018.

[5] M. Geissdoerfer, P. Savaget, N. M. P. Bocken, and E. J. Hultink, 'The circular economy - A new sustainability paradigm?', J. Clean. Prod., vol. 143, pp. 757-768, Feb. 2017.

[6] F. Acerbi and M. Taisch, 'A literature review on circular economy adoption in the manufacturing sector', J. Clean. Prod., vol. 273, Jul. 2020, Art. no. 123086.

[7] J. A. Garza-Reyes, A. Salomé Valls, S. Peter Nadeem, A. Anosike, and V. Kumar, 'A circularity measurement toolkit for manufacturing SMEs', Int. J. Prod. Res., vol. 57, no. 23, pp. 7319-7343, 2019.

[8] Ellen MacArthur Foundation, Towards a Circular Economy: Business Rationale for an Accelerated Transition. Cowes, UK: Ellen MacArthur Foundation, 2015.

[9] P. Valkokari, N. Tura, M. Ståhle, J. Hanski, and T. Ahola, Advancing Circular Business. Tampere, Finland: Tampere University, 2019.

[10] E. Kristoffersen, F. Blomsma, P. Mikalef, and J. Li, 'The smart circular economy: A digital-enabled circular strategies framework for manufacturing companies', J. Bus. Res., vol. 120, pp. 241-261, Nov. 2020.

[11] J. L. Mishra, K. D. Chiwenga, and K. Ali, 'Collaboration as an enabler for circular economy: A case study of a developing country', Manag. Decis., to be published.

[12] S. Rajput and S. P. Singh, 'Connecting circular economy and industry 4.0', Int. J. Inf. Manage., vol. 49, pp. 98-113, Mar. 2019.

[13] H. Parikka, T. Härkönen, and J. Sinipuro, A Fair Data Economy is Built Upon Collaboration. Helsinki, Finland: Sitra, 2021.

[14] Sitra, Technology Industries of Finland, and Accenture, Circular Economy Business Models for the Manufacturing Industry: Circular Economy Playbook for Finnish SMEs. Helsinki, Finland: Sitra, Technology Industries of Finland, and Accenture, 2020.

[15] M. A. Khan and T. Wuest, 'Upgradable product-service systems: Implications for business model components', Procedia CIRP, vol. 80, pp. 768-773, 2019.

[16] D. Romero and A. Molina, 'Green virtual enterprise breeding environments: A sustainable industrial development model for a circular economy', in Collaborative Networks in the Internet of Services, PRO-VE 2012. IFIP Advances in Information and Communication Technology, pp. 427-436.

[17] H. P. Wallner and M. Narodoslawsky, 'The concept of sustainable islands: Cleaner production, industrial ecology and the network paradigm as preconditions for regional sustainable development', J. Clean. Prod., vol. 2, no. 3-4, pp. 167-171, 1994. 
[18] M. Paloneva and S. Takamäki, Summary of Sector-Specific Low-Carbon Roadmaps. Helsinki, Finland: Ministry of Economic Affairs and Employment, 2021.

[19] V. Rizos et al., 'Implementation of circular economy business models by small and medium-sized enterprises (SMEs): Barriers and enablers', Sustain., vol. 8, no. 11, Nov. 2016.

[20] F. Blomsma et al., 'Developing a circular strategies framework for manufacturing companies to support circular economy-oriented innovation', J. Clean. Prod., vol. 241, Dec. 2019.

[21] E. Ünal and J. Shao, 'A taxonomy of circular economy implementation strategies for manufacturing firms: Analysis of 391 cradle-to-cradle products', J. Clean. Prod., vol. 212, pp. 754-765, Mar. 2019.

[22] I. Barletta, M. Despeisse, S. Hoffenson, and B. Johansson, 'Organisational sustainability readiness: A model and assessment tool for manufacturing companies', J. Clean. Prod., vol. 284, 2021, Art. no. 125404.

[23] R. Teichert, 'Digital transformation maturity: A systematic review of literature', Acta Univ. Agric. Silvic. Mendelianae Brun., vol. 67, no. 6, pp. 1673-1687, Dec. 2019.

[24] O. Kuusisto, J. Kääriäinen, K. Hänninen, and M. Saarela, 'Towards a micro-enterprisefocused digital maturity framework', Int. J. Innov. Digit. Econ., vol. 12, no. 1, pp. $72-$ $85,2020$.

[25] L. Saari, O. Kuusisto, and J. Häikiö, 'ManuMaturity - The maturity tool for manufacturing companies to reach beyond Industry 4.0', VTT Technical Research Centre of Finland, Oulu, Finland, 2021.

[26] F. Acerbi and M. Taisch, 'Information flows supporting circular economy adoption in the manufacturing sector', in IFIP International Conference on Advances in Production Management Systems 2020, pp. 703-710.

[27] K. Peffers, M. Rothenberger, T. Tuunanen, and R. Vaezi, 'Design science research evaluation. Design Science Research in Information Systems', in Design Science Research in Information Systems. Advances in Theory and Practice. 7th International Conference, DESRIST 2012 Las Vegas, NV, USA, May 14-15, 2012 Proceedings, pp. 398-410.

[28] F. Acerbi, V. Järnefelt, J. T. Martins, L. Saari, K. Valkokari, and M. Taisch, 'Developing a qualitative maturity scale for circularity in manufacturing', to be presented at Advances in Production and Management Systems 2021 IFIP International Conference, Nantes, France, Sep. 5-9, 2021. 